\begin{abstract}
Iranica
Abstracta Iranica Revue bibliographique pour le domaine irano-aryen

Volume 37-38-39 | 2018

Comptes rendus des publications de 2014-2016
\end{abstract}

\title{
Josette Elayi, Alain G. Elayi. Phoenician Coinages
}

\section{Astrid Nunn}

\section{OpenEdition}

\section{Journals}

Édition électronique

URL : http://journals.openedition.org/abstractairanica/42609

DOI : 10.4000/abstractairanica.42609

ISBN : 1961-960X

ISSN : 1961-960X

Éditeur :

CNRS (UMR 7528 Mondes iraniens et indiens), Éditions de l'IFRI

Référence électronique

Astrid Nunn, « Josette Elayi, Alain G. Elayi. Phoenician Coinages », Abstracta Iranica [En ligne], Volume 37-38-39 | 2018, document 17, mis en ligne le 10 mars 2018, consulté le 10 décembre 2020. URL : http://journals.openedition.org/abstractairanica/42609; DOI : https://doi.org/10.4000/ abstractairanica.42609

Ce document a été généré automatiquement le 10 décembre 2020.

Tous droits réservés 


\title{
Josette Elayi, Alain G. Elayi. Phoenician Coinages
}

\author{
Astrid Nunn
}

\section{RÉFÉRENCE}

Josette Elayi, Alain G. Elayi. Phoenician Coinages, (Transeuphratène, Supplément 18), Gabalda, Paris, 2014, 2 vol., 600 p., 86 planches.

1 Ce nouveau volume devait rassembler tous les articles - éparpillés et partiellement difficiles d'accès - que les $A$. ont publiés sur les monnaies que les cités phéniciennes Sidon, Tyr, Byblos et Arwad ont frappées jusqu'à la fin de l'époque achéménide. Vu qu'un seul volume ne contient pas leurs 80 articles, les A. ont choisi d'en republier 55 intégralement et de résumer les autres ainsi que leurs monographies.

2 La typographie des articles de sources diverses a été uniformisée ce qui en fait un «vrai » livre. Plusieurs listes des rois phéniciens ainsi que de l'iconographie et des inscriptions numismatiques récapitulent les résultats et les mettent à jour. La nouvelle méthode métrologique développée par les A. est également présentée.

\section{AUTEURS}

\section{ASTRID NUNN}

Université de Munich 